Pricing Beauty 


\section{Pricing Beauty}

The Making of a Fashion Model

\section{Ashley Mears}

\section{甲}

UNIVERSITY OF CALIFORNIA PRESS

Berkeley • Los Angeles • London 
University of California Press, one of the most distinguished university presses in the United States, enriches lives around the world by advancing scholarship in the humanities, social sciences, and natural sciences. Its activities are supported by the UC Press Foundation and by philanthropic contributions from individuals and institutions. For more information, visit www.ucpress.edu.

University of California Press

Berkeley and Los Angeles, California

University of California Press, Ltd.

London, England

(C) 20I I by The Regents of the University of California

Photographs courtesy of Beowulf Sheehan, except as noted.

Library of Congress Cataloging-in-Publication Data

Mears, Ashley, I980-

Pricing beauty : the making of a fashion model /

Ashley Mears.

p. $\mathrm{cm}$.

Includes bibliographical references and index. ISBN 978-0-520-26033-7 (cloth : alk. paper) ISBN 978-0-520-27076-3 (pbk. : alk. paper)

I. Models (Persons) 2. Modeling agencies.

3. Fashion shows. I. Title.

HD8039.M77M43 20 I I

$338.4^{\prime} 774692-\mathrm{dc} 22$

2011006003

Manufactured in the United States of America
20 I9 I8 I7 46 I5 I4 I3 I2 II

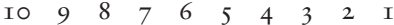

This book is printed on Cascades Enviro I00, a I00\% post consumer waste, recycled, de-inked fiber. FSC recycled certified and processed chlorine free. It is acid free, Ecologo certified, and manufactured by BioGas energy. 
To Jennifer 